\title{
A method of digital processing of the shape of impulses applied to investigation of promising scintillators
}

\author{
S.S.Markochev, N.V.Eremin, V.I.Arbuzov" \\ FSUE "CNIIHM", 115487 Moscow, Russia \\ "FSUE SIC "S.Vavilov State Optical Institute", \\ 199034 St. Petersburg, Russia
}

Received March 12, 2013

\begin{abstract}
Spectrometer on the basis of digital storage oscilloscope Tektronix TDS 7704B for the study of scintillation characteristics of promising scintillators is described. Digital waveforms of anodic impulses from PMT photomultiplier were stored and processed in off-line mode. The measured maximum counting rate of impulses was $1.8 \cdot 10^{5} \mathrm{imp}$./s. The results of the experimental research of the scintillation characteristics of enriched ${ }^{6} \mathrm{Li}$-silicate glass, manufactured in SIC "S.Vavilov State Optical Institute", is presented. The energy resolution $(\mathrm{FWHM})$ of the peak from ${ }^{6} \mathrm{Li}\left(n_{\text {therm }}, \alpha\right) T$ reaction of thermal neutrons with ${ }^{6} \mathrm{Li}$ was $23 \%$. Scintillation times of the glass for $\alpha$ - and $\gamma$-sources were measured; the possibility of additional discrimination of thermal neutrons and $\gamma$-quanta by the shape of impulses is presented.
\end{abstract}

Описан спектрометр на основе цифрового запоминающего осциллографа Tektronix TDS 7704B для исследования сцинтилляционных характеристик перспективных сцинтилляторов. Цифровые осциллограммы анодных импульсов ФЭУ запоминаются и обрабатываются в режиме off-line. Максимальная скорость регистрации импульсов составила $1.8 \cdot 10^{5}$ имп./сек. Приведены результаты экспериментального исследования сцинтилляционных свойств обогащенного ${ }^{6} \mathrm{Li}$-литиевого стекла, изготовленного в НПК ГОИ им. С.Вавилова. Энергетическое разрешение пика тепловых нейтронов от ${ }^{6} \mathrm{Li}\left(n_{\text {therm }}, \alpha\right) T$ peакции с ${ }^{6} \mathrm{Li}$ составило $23 \%$. Измерены времена высвечивания импульсов от $\alpha$ - и $\gamma$-источников, показана возможность дополнительного разделения тепловых нейтронов и $\gamma$-квантов по форме импульса.

Метод цифрової обробки форми імпульсів у застосуванні до дослідження перспективних сцинтиляторів. С.С.Маркочев, Н.В.Єрьомін, В.І.Арбузов.

Описано спектрометр на основі цифрового запам'ятовуючого осцилографа Tektronix TDS 7704B для дослідження сцинтиляційних характеристик перспективних сцинтиляторів. Цифрові осцилограми анодних імпульсів ФЕУ запам'ятовуються і обробляються в режимі off-line. Максимальна швидкість реєстрації імпульсів склала $1.8 \cdot 10^{5}$ імп./сек. Наведено результати експериментального дослідження сцинтиляційних властивостей збагаченого ${ }^{6} \mathrm{Li}$-літієвого склав, виготовленого в HBK ГOI ім. C.Вавілова. Енергетичний дозвіл піку теплових нейтронів від ${ }^{6} \mathrm{Li}\left(n_{\text {therm }}, \alpha\right) T$ реакції с ${ }^{6} \mathrm{Li}$ склало $23 \%$. Виміряно часи висвічування імпульсів від $\alpha$ - і $\gamma$-джерел, показано можливість додаткового поділу теплових нейтронів і $\gamma$-квантів за формою імпульсу. 


\section{Introduction}

One of the urgent problems in nuclear radiation spectroscopy is a search for new promising scintillators for selective registration of neutrons instead of ${ }^{3} \mathrm{He}$-counters. One of such scintillators is enriched ${ }^{6} \mathrm{Li}$-silicate glass, activated cerium [1], the study of scintillation characteristics of which is devoted to this work.

Usage of a digital storage oscilloscope for measuring scintillation characteristics of promising scintillators is caused by the necessity to obtain more useful information about the response to radiation, than that which is available by analog electronics. Signal digitization allows to process experimental data repeatedly and to optimize the developed algorithms of processing the shape of light emission impulse - to take into account pile-up effect and the baseline shift, to find time reference point to the signal with an accuracy of up to fractions of a nanosecond, to recover energy spectra of the registered radiation.

Digital storage oscilloscopes are recently being used, for example, to distinguish charged particles by the shape of impulses [2], as well as neutrons and $\gamma$-quanta $[3,4]$. In [2] it was used a spectrometer on the basis of scintillator CsI(TI), in [3, 4] - spectrometer on the basis of stilbene. Counting rate of the detector in [4] has reached $\sim 10^{6} \mathrm{imp}$./s, which is exceed the possibility of analog electronics. The digital method is also applied for investigation of amplitudetemporal properties of inorganic scintillators [5].

Selective registration of neutron radiation requires effective subtraction of background events. By using the digital method, one can improve the selectivity of the promising scintillator through use of the algorithms for differentiation of the types of nuclear radiation by the shape of impulses.

\section{Experimental}

Lithium-silicate glass had a composition $\mathrm{SiO}_{2}-\mathrm{Li}_{2} \mathrm{O}-\mathrm{MgO}-\mathrm{Al}_{2} \mathrm{O}_{3}-\mathrm{Ce}$ with the concentration of the isotope ${ }^{6} \mathrm{Li}$ equal to $1.13 \cdot 10^{22} \mathrm{~cm}^{-3}$, was manufactured in SIC "S.Vavilov State Optical Institute". Spectrometer for investigation of the scintillation characteristics of the glass was consisted of compact photomultiplier tube Hamamatsu R5611a and four-channel digital storage oscilloscope Tektronix TDS 7704B with a bandwidth of $7 \mathrm{MHz}$ and maximum sampling rate of $20 \mathrm{MHz}$. For

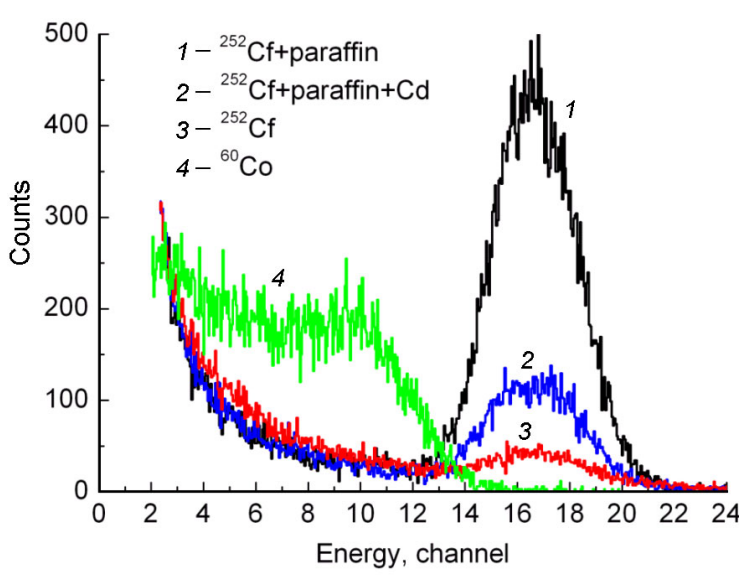

Fig. 1. Measured responses of the enriched ${ }^{6}$ Li-silicate glass on thermal neutrons and $\gamma$-quanta from ${ }^{252} \mathrm{Cf}$ and ${ }^{60} \mathrm{Co}$ sources.

digitizing the shapes of lithium glass impulses the sampling time was chosen to be equal to $0.1 \mathrm{~ns}$, the length of one record $10^{4}$ points. At the selected time settings of the oscilloscope its maximum counting rate of impulses was measured to be equal to $1.8 \cdot 10^{5} \mathrm{imp} . / \mathrm{s}$ with the help of digital functional generator Tektronix AFG 3102 .

Digitized waveforms were recorded in the oscilloscope memory $\left(6.4 \cdot 10^{7}\right.$ points), and after its completion were saved as a file. Operation of the oscilloscope (his settings reinstallation, saving of digitized shapes of impulses) was carried out by special software, written in $\mathrm{C}++$ language, using the Plug\&Play driver of the oscilloscope and the interface of input/output TekVisa. Software allowed to conduct experiments in automatic mode according to a preconceived plan.

Recorded in the file waveforms were processed in off-line mode on personal computer with the help of the developed digital algorithms and the graphical user interface (GUI) in MatLab package. GUI allowed controlling the results of the experimental data processing and presenting them in the form of graphs. Time reference points to impulses were found by the method of constant-fraction - on the edge of impulses at the height of $1 / 3$ of its amplitude. Impulse energy was estimated by integrating a signal in the time window $-30 \ldots 350$ ns relative to its time reference point.

\section{Results and discussion}

The sample of $16 \times 16 \times 6 \mathrm{~mm}^{3}$ lithium-silicate glass was irradiated by the flux of thermal neutrons from a ${ }^{252} \mathrm{Cf}$ source with 


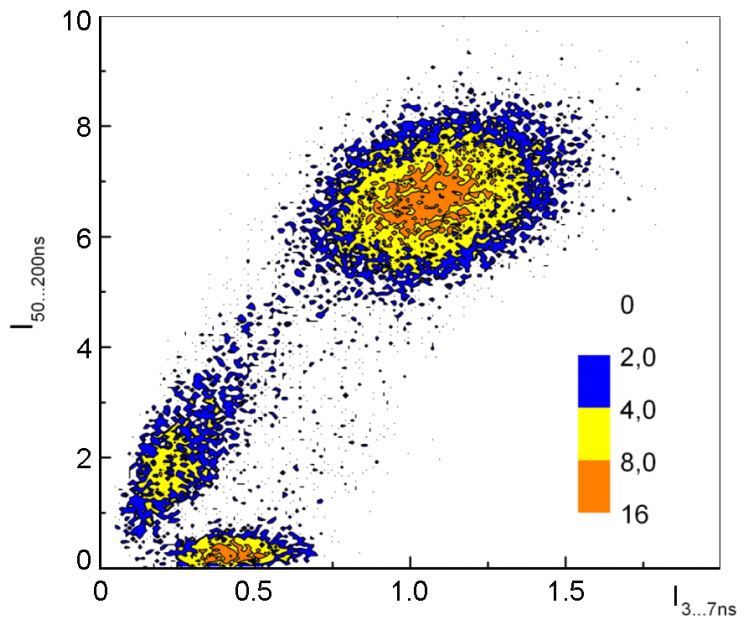

Fig. 2. $\alpha$-Particles (from ${ }^{6} \mathrm{Li}\left(n_{\text {therm }} \alpha\right) T$ reaction) discrimination in the experiment with ${ }^{252} \mathrm{Cf}$ source within the paraffin sphere.

activity $\sim 3.2 \cdot 10^{5}$ neutron/s, which was placed in the center of paraffin sphere with a diameter $14 \mathrm{~cm}$. The distance from the source to the glass was $\approx 30 \mathrm{~cm}$. The experiment was carried out in three ways: 1 ) with the source of ${ }^{252} \mathrm{Cf}$ without paraffin; 2) the source of ${ }^{252} \mathrm{Cf}$ was placed in the center of paraffin sphere; 3) with paraffin and with cadmium sheet with thickness of $0.6 \mathrm{~mm}$, installed between the source and the glass.

The measured responses of the enriched 6 Li-silicate glass on thermal neutrons and $\gamma$-quanta from ${ }^{252} \mathrm{Cf}$ and ${ }^{60} \mathrm{Co}$, respectively, are shown in Fig. 1. Experiments with ${ }^{252} \mathrm{Cf}$ have shown the peak from ${ }^{6} \mathrm{Li}\left(n_{\text {therm }}, \alpha\right) T$ reaction of thermal neutrons with ${ }^{6} \mathrm{Li}$, whereas in the experiment with ${ }^{60} \mathrm{Co}$ this peak was not observed. In the case of settings 1 and 3 the peak was due to deceleration of neutrons from ${ }^{252} \mathrm{Cf}$ by the surrounding objects. The energy resolution (FWHM) of the peak was $23 \%$.

The scintillation time measurements of the enriched 6 Li-silicate glass were made with $\alpha$-source of ${ }^{238} \mathrm{Pu}$ and $\gamma$-source of ${ }^{60} \mathrm{Co}$. Recorded shapes of impulses were approximated by decreasing exponent with a parameter $\tau$. For $\alpha$-particles the value of the parameter is equal to $\tau_{\alpha}=56 \pm 13 \mathrm{~ns}$, for $\gamma$-quanta $-\tau_{\gamma}=80 \pm 12$ ns. Approximating the falling part of the investigated glass impulse by the sum of two exponents was failed.

On the basis of the dependence the scintillation time of lithium glass on the type of nuclear radiation a simple method of $\alpha$-particles discrimination (and, consequently,

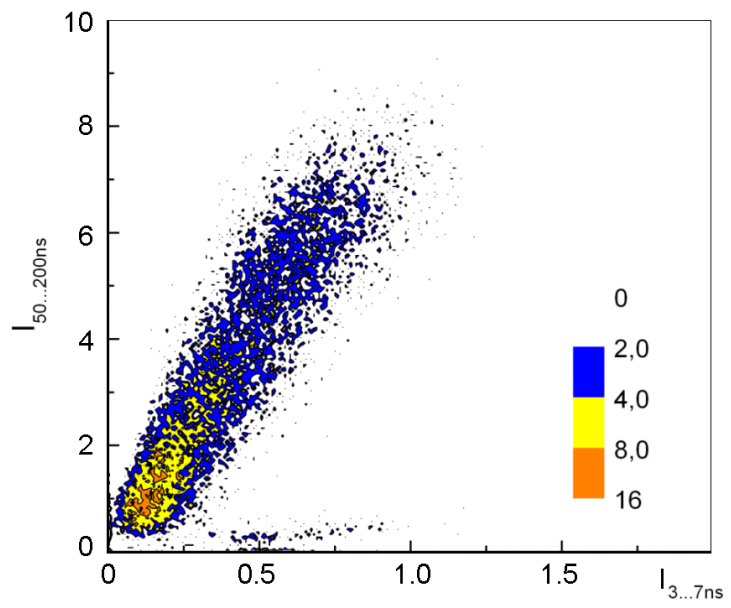

Fig. 3. Result of the particles discrimination by the impulses shape in the experiment with ${ }^{60} \mathrm{Co}$ source.

thermal neutrons) was developed. Two time windows relative to the time reference point were chosen for discrimination particles by integration of impulses within the windows. The best resolution of the peak from thermal neutrons was observed at the time windows $T_{1}=3 . .7 \mathrm{~ns}$ and $T_{2}=50 . .200 \mathrm{~ns}$ relative to a time reference point. The result of $\alpha$-particles discrimination in the experiment with the ${ }^{252} \mathrm{Cf}$ source within the paraffin sphere is presented in Fig. 2. The result of the particles discrimination by the shape of impulses in the experiment with ${ }^{60} \mathrm{Co}$ source is presented in Fig. 3. $I_{1}$ and $I_{2}$ on the axes of both figures denote the integrals of impulses in the corresponding time windows $T_{1}$ and $T_{2}$. By comparing two figures one can make a conclusion that observable peak is really corresponds to the peak from ${ }^{6} \mathrm{Li}\left(n_{\text {therm }}, \alpha\right) T$ reaction of thermal neutrons with $6 \mathrm{Li}$.

\section{Conclusions}

The developed digital method for investigation of promising scintillators was used for experimental study of the registration efficiency of lithium glass, enriched by the isotope ${ }^{6} \mathrm{Li}$, on thermal neutrons. The glass was manufactured in SIC "S.Vavilov State Optical Institute". By using the digital signal processing the scintillation times have been measured for $\alpha$-particles and $\gamma$-quanta; the possibility of selective registration of neutron radiation by the shape of lithium glass impulse have been shown. The developed method can be applied to studies of other promising scintillators. 


\section{References}

1. B.V.Shulgin, V.L.Petrov, V.A.Pustovarov et al., Phys. Solid State, 47, 1464 (2005).

2. V.A.Khryachkov, M.V.Dunaev et al., Pribory $i$ Tekhnika Eksperimenta, 3, 29 (2000).

3. M.V.Prokuronov, A.A.Golubev et al., Pribory i Tekhnika Eksperimenta, 2, 67 (2006).
4. M.V.Prokuronov, A.N.Shabalin, Pribory $i$ Tekhnika Eksperimenta, 3, 31 (2007).

5. N.V.Eremin, S.S.Markochev, A.A.Paskhalov, Book of Abstracts 60 Int. Conf. on Nuclear Physics "Nucleus 2010", St.Petersburg (2010), p.363. 